Alina Vysochyna,

Ph.D., Sumy State University, Ukraine

iD ORCID ID, 0000-0001-9490-1026

email: a.vysochyna@uabs.sumdu.edu.ua

Olena Kryklii,

Ph.D., Sumy State University, Ukraine

ORCID ID, 0000-0002-4825-3950

email: o.kryklii@uabs.sumdu.edu.ua

Mariia Minchenko,

Ph.D., Sumy State University, Ukraine

email:m.minchenko@uabs.sumdu.edu.ua

Aygun Akbar Aliyeva,

Ph.D., Institute of Control Systems of National Academy of Sciences of Azerbaijan, Azerbaijan

(iD) ORCID ID, 0000-0003-4660-9324

email: aliyevaaygun1978@gmail.com

Kateryna Demchuk,

University of Applied Sciences of Hamburg, Hamburg

(iD) ORCID ID, 0000-0001-9556-1625

email: katerynademchuk@icloud.com

Correspondence author: a.vysochyna@uabs.sumdu.edu.ua

\title{
COUNTRY INNOVATIVE DEVELOPMENT: IMPACT OF SHADOW ECONOMY
}

Abstract. This article generalises arguments and counterarguments within the scientific discussion regarding the determination of the influence of illegal economic activity and expansion of the shadow economy on innovative country development. The systematisation of the scientific works on the above problems proves that there is no one no complexity and unity in the above-mentioned scientific findings, which, in turn, demonstrates the necessity of further theoretical and empirical search in this sphere. Thus, it was developed a scientific hypothesis about the negative influence of the shadow economy on innovative country development. In order to test this hypothesis it was developed a scientific and methodological approach that consists of several stages: 1) correlation analysis in order to eliminate multicollinearity problem between control variables; 2) analysis of dataset descriptive statistics; 3) running Hausman test in order to clarify specification of the regression model (fixed or random effects model); 4) realisation of the panel data regression analysis for the whole country sample and separately for Ukraine, characteristics of its results. Technically all stages of the research are realised with the help of Stata 12/S.E. software. The country sample consists of 9 countries (Azerbaijan, Estonia, Hungary, Latvia, Lithuania, Poland, Slovak Republic, Slovenia, and Ukraine). Time horizon - 2008-2018. Running of the panel data regression analysis (model specification - with fixed effects) allow confirming research hypothesis for the whole country sample (an increase of shadow economy negatively affected innovative country development: an increase of shadow economy to GDP ratio in $1 \%$ leads to the decrease of the Global Innovation Index in 0.5 points). However, it was not proved for Ukraine separately. It leads to the conclusion that innovative development in Ukraine does not highly dependent on the shadow economy scale because of more significant obstacles on the way on innovation adoption (institutional inefficiency, regulatory drawbacks etc.).

Keywords: innovative economic growth, innovative state management, panel data analysis, shadow economy.

Introduction. Globalisation has become one of the defining characteristics of the modern world economy. Thus, it raises the problem of finding new forms and methods of adapting the national economic

Cite as: Vysochyna, A., Kryklii, O., Minchenko, M., Aliyeva, A. A., \& Demchuk, K. (2020). Country Innovative Development: Impact of Shadow Economy. Marketing and Management of Innovations, 4, 41-49. http://doi.org/10.21272/mmi.2020.4-03 
and political environment before for external and internal challenges. Rapid changes in the factors that determine the competitiveness of individual firms and the entire country in world markets, the dynamic development of global relations are forcing governments to shape the conditions of economic growth and increasingly address the problems of national competitiveness on a global scale. Ukraine's transition to innovative development is essential for increasing the competitiveness of the domestic economy from a global perspective.

In terms of boosting Ukraine's innovative development, it could be pointed out that Ukraine has significant unrealised opportunities in innovative development, especially in terms of commercialisation of innovations and in the field of protection of intellectual property rights. The main advantages of Ukraine are favourable geographical location, capacious market, and presence of an in-depth and comprehensive free trade area between Ukraine and the EU member countries, and a relatively high level of human development. In turn, among factors inhibiting Ukraine's innovative development we can identify as follows: high ration of illegal entrepreneurial activity and the shadow economy, the significant scale of tax evasion, moral and physical insufficiency of production equipment, high level of corruption, lack of legislative regulation etc.

Thus, in order to solve these problems, it needs to understand the scale up to which all the factors as mentioned above were inhibiting country innovative development in Ukraine and neighbour countries. That is why in this research we are going to test the hypothesis about the negative influence of an expansion of shadow operations on dynamics of innovative country development and clarify such relationships for the country sample from 9 neighbour countries and specifically for Ukraine based on correlation and regression analysis.

Literature Review. There is some scientific research that is focusing on clarification of factors affecting country innovative development, including relationships between this parameter and scale of shadow economy expansion. Research of the preconditions of innovative development could be subdivided into three groups: the first group of researchers are focused on microeconomic perspectives of innovative development, the second - on the regional and municipal level, the third - on national and supranational. In terms of the characteristic of the first set of research, we might pay attention to findings described by Boyarko and Samusevych (2011), Bonamigo and Mendes (2019). Specifically, they argued that company development and increase of its value is impossible without investments in intangible assets and innovations. Umadia and Kasztelnik (2020) also clarifying macroeconomic perspectives of ensuring innovative company development. Authors concluded that an improvement in employment level, general production level, and economic growth positively influence innovation expansion both at corporate and national levels. In turn, Biewendt et al. (2020) also strongly support the idea that company sustainable development depends on the implementation of innovations.

Specifically, the authors proved that investment in green controlling, IT and technological modernisation might help to increase business performance and sustainability. Moreover, Akhondzadeh (2019), Goncharenko (2020) mentioned that an increase of company research and development expenditures might help to improve business survival and growth, especially in the case of small and medium enterprises. In turn, Tsalikis and Seaton (2020), Jahan (2019), Kaya (2020), Tommaso and Gulinelli (2019) declared that corporate social responsibility and investment in innovations might become a significant driver of business performance improvement. At the same time, Delanoy and Kasztelnik (2020) argued that innovative managerial approach implementation might result in the increase of consumers loyalty and consequently, business profitability.

In turn, Singh (2018) characterised the problem of innovative development from a regional perspective and pointed out that expansion of financing of regional development innovative projects might create a background for the whole country innovatively oriented sustainable development. 
Finally, the third group of scientists focused on macroeconomic consequences and preconditions of innovative country development. Vasylieva and Kasyanenko (2013) argued that national economy innovation potential of Ukraine might be quantitatively assessed considering financial, labour and material parameters. In turn, Vasylieva et al. (2018), Lyeonov et al. (2019), Kuzmenko et al. (2020) pointed out that financing of innovations might become a precondition of ensuring macroeconomic stability, while an increase of illegal operations and shadow economy negatively affected not only innovation activity dynamics but also general country macroeconomic stability.

In turn, Yarovenko et al. (2020a), Yarovenko et al. (2020b) pointed out that lack of information security might negatively affect country economic and innovative development (based on data for 59 countries of the world using CRR and BCC models). Moreover, Lopez and Alcaide (2020) mentioned that the implementation of information innovations might help to overcome negative consequences of economic, social and political crisis. Therefore, Zolkover and Terziev (2020) found out that shadow economy might damage numerous macroeconomic parameters such as employment, environmental sustainability, innovation development etc. Thus, based on the literature review results, it has become apparent that there is no complexity and unity in the above-mentioned scientific findings, which, in turn, proves the necessity of further theoretical and empirical search in this sphere.

Methodology and research methods. The research aims to test the hypothesis about the negative influence of an expansion of shadow operations on the dynamics of innovative country development. It is necessary to highlight that as a proxy of country innovative development (dependent variable) it is proposed to choose the Global Innovation Index (variable marker - GII). It is calculated by experts from Cornell University, Business School INSEAD, and the World Intellectual Property Organization (WIPO). This Index is calculated from 2007 and allows measuring innovative macroeconomic development from different perspectives. In 2020 it covers 131 countries. Global Innovation Index assesses innovative country development in several perspectives, namely:

1) institutions (political environment, regulatory environment, business environment);

2) human capital and research (education, tertiary education, research and development);

3) infrastructure (informational and communication technologies, general infrastructure, ecological infrastructure);

4) market sophistication (credit, investment, trade, competition, and market scale);

5) business sophistication (knowledge workers, innovation linkages, knowledge absorption);

6 ) knowledge and technological outputs (knowledge creation, knowledge impact, knowledge diffusion);

7) creative outputs (intangible assets, creative goods and services, online creativity).

Each of the perspectives mentioned above is based on quantitatively measured indicators. It also should be mentioned that these seven perspectives of innovative country development are assessed both separately and on the complex. In general, the Global Innovation Index is measured on a scale from 0 to 100 , where 100 is the most innovatively developed economy. In terms of characteristics of Ukraine's position in the Global Innovation Index, it could be mentioned that in 2020 it has 45 of 131 positions while in 2019, it was 2 positions lower (47). The worst situation in Ukraine with market sophistication (42.1 points and 99th position), infrastructure (33.1 points and 94th position) and institutions (55.6 points and 93rd position). In turn, by far better situation in Ukraine is with business sophistication (29.5 points and 54th position), creative outputs (29.9 points and 44th position), human capital and research (40.5 points and 39th position), and knowledge and technological outputs (35.1 points and 25th position). It also should be mentioned that as a measure of the shadow economy (independent variable) is chosen and indicator of shadow economy to GDP ratio, which is calculated based on the MIMIC model by Leandro Medina and Friedrich Schneider (Medina and Schneider, 2018). 
Thus, the paper tested the hypothesis about the negative impact of the shadow economy on country innovative development. The multiple regression was used. In order to raise the quality of modelling, the scientists included additional variables to the model - control variables, which influence country economic and innovative development. Consequently, a subset of the control variables is as follows:

- consumer price index $(2010-100 \%)(\mathrm{CPI})$ is a parameter, which demonstrates the price stability of the country's economy;

- current account balance (Balance of Payments, current USD) (CAB);

- employment to population ratio, 15+ (\%) (modelled ILO estimate) (Empl) is a parameter, which describes the labour potential of the national economy;

- foreign direct investment, net (Balance of Payments, current USD) (FDI) and gross capital formation (current USD) (GCF) describe the state's investment and innovative potential;

- GDP growth (annual \%) (GDPg);

- trade openness (ratio of total export and import amount to GDP), \% (Trade) - enables to evaluate the country's international activity potential.

The relevance of such a set of control variables is proved by numerous empirical research results (Bhowmik, 2018; Hrytsenko et al., 2018; AUgbaka et al., 2019; Toyin and Oludayol, 2020). All control variables are collected from the World Development Indicators collection of the World Bank. The country sample consists of 9 countries such as Azerbaijan, Estonia, Hungary, Latvia, Lithuania, Poland, Slovak Republic, Slovenia, and Ukraine. Time horizon - 2008-2018, because some data is not available for the whole country sample in later periods. In order to fulfil the task of the research, it is proposed to go through the next steps: to realise correlation analysis in order to eliminate multicollinearity problem between control variables; to analyse dataset descriptive statistics; to run the Hausman test in order to clarify the specification of the regression model (fixed or random effects model); to run panel data regression analysis for the whole country sample and characterise its results; to run regression analysis specifically for Ukraine and characterise its results. Technically all stages of the research are realised with the help of Stata 12/S.E. software.

Results. Thus, the first stage of the research aimed at testing the hypothesis about the negative influence of shadow economy on innovative country development is correlation analysis, which is realised in order to eliminate collinearity between control variables. The correlation matrix is in table 1.

Table 1. Correlation matrix of control variables

\begin{tabular}{lccccccr}
\hline Variables & $(\mathbf{1})$ & $\mathbf{( 2 )}$ & $\mathbf{( 3 )}$ & $\mathbf{( 4 )}$ & $\mathbf{( 5 )}$ & $\mathbf{( 7 )}$ & $\mathbf{( 8 )}$ \\
\hline (1) CPI & 1.000 & & & & & & \\
(2) CAB & 0.107 & 1.000 & & & & & \\
(3) Empl & -0.109 & 0.311 & 1.000 & & & & \\
(4) FDI & 0.023 & 0.632 & 0.323 & 1.000 & & & \\
(5) GDPg & 0.068 & -0.105 & 0.134 & -0.208 & 1.000 & & \\
(7) GCF & -0.083 & -0.656 & -0.353 & -0.415 & 0.203 & 1.000 & \\
(8) Trade & -0.119 & 0.562 & 0.123 & 0.473 & 0.306 & -0.435 & 1.000 \\
\hline
\end{tabular}

Notes: CPI - consumer price index; $\mathrm{CAB}$ - current account balance; Empl - employment to population ratio; FDI - foreign direct investment, net; GCF - gross capital formation; GDPg - GDP growth; Trade - trade openness (ratio of total export and import amount to GDP).

Sources: developed by the authors.

Based on the correlation analysis results it should be mentioned that there is a significant correlation between three variables, namely: current account balance (Balance of Payments, current USD) (CAB) and foreign direct investment, net (Balance of Payments, current USD) (FDI) and gross capital formation 

Economy

(current USD) (GCF) (these cells are shadowed). In order to eliminated multicollinearity problem is needed to eliminate one or several variables. One of the possible ways of clarification a variable that is needed to be excluded from further modelling is the calculation of an average correlation coefficient for all variables that are in focus on this stage. Thus, our calculations showed that the variable "current account balance» has coefficient 0.3925 , variable «gross capital formation» - 0.3637 , and variable «foreign direct investments» -0.3846 . Therefore, the highest value of an averaged correlation coefficient has such control variable as «current account balance», so it is proposed to exclude it from the regression analysis in order to avoid multicollinearity problem. After its elimination, it was realised correlation analysis one more time, and it was proved that there are not any highly correlated control variables. The next stage of the research is the general characteristics of the descriptive statistics measures (table 2). First, it should be mentioned that the panel is firmly balanced because it does not have omitted observations that are proved by the value of observations. It also points out that in 9 selected countries and averaged value of Global Innovation Index is 40.9 points, the share of the shadow economy in GDP $-20.1 \%$, consumer price index growth in comparison with 2010 price level - 110.3\%, employment to population ratio - 46.7\%, net foreign direct investments $-2.53 \cdot 10^{9}$ US Dollars, GDP growth - $1.4 \%$, gross capital formation $3.10 \cdot 10^{10}$ US Dollars, trade openness (ration of the sum of export and import to GDP) $-135.3 \%$.

Table 2. Descriptive statistics

\begin{tabular}{lccccc}
\hline \multicolumn{1}{c}{ Variable } & $\begin{array}{c}\text { Observatio } \\
\mathbf{n}\end{array}$ & Mean & $\begin{array}{c}\text { Standard } \\
\text { Deviation }\end{array}$ & Min & Max \\
\hline GII & 99 & 40.902 & 7.074 & 22.4 & 55.3 \\
Shadow & 99 & 20.104 & 8.39 & 9.99 & 43.53 \\
CPI & 99 & 110.329 & 24.452 & 78.9 & 261.07 \\
Empl & 99 & 46.72 & 3.476 & 38.63 & 54.11 \\
FDI & 99 & $-2.53 e+09$ & $3.28 \mathrm{e}+09$ & $-1.48 \mathrm{e}+10$ & $2.03 \mathrm{e}+09$ \\
GDPg & 99 & 1.422 & 4.538 & -14.81 & 7.44 \\
GCF & 99 & $3.10 \mathrm{e}+10$ & $3.17 \mathrm{e}+10$ & $4.12 \mathrm{e}+09$ & $1.32 \mathrm{e}+11$ \\
Trade & 99 & 135.286 & 28.757 & 75.23 & 190.16 \\
\hline \multicolumn{2}{c}{ Notes: Gll - Global Innovation Index; Shadow - the ratio of the shadow economy in GDP; CPI - consumer price }
\end{tabular}
index; Empl - employment to population ratio; FDI - foreign direct investment, net; GCF - gross capital formation; GDPg - GDP growth; Trade - trade openness (ratio of total export and import amount to GDP).

Sources: developed by the authors.

The next stage of the research is the identification of the specification of the model that better fits the data in terms of testing the hypothesis about the negative influence of the shadow economy on innovative country development. Consequently, the Hausman test allows identifying that better model specification is panel data regression with fixed effects that also allows us concluding that country-specific characteristics of economic development do influence variation of its innovative development progress. After the identification of model specification, we are moving to the next stage - regression analysis for the whole country sample (panel data). Results of the panel data regression analysis for 9 countries are in Table 3. Based on the data from Table 3, it is possible to make the following conclusions:

- the model is adequate because the value of the coefficient of determination is 0.653 that means that variation of independent and control variables explain $65.3 \%$ of the dependent variable variation;

- an increase of shadow economy negatively affected innovative country development: an increase of shadow economy to GDP ratio in $1 \%$ leads to the decrease of the Global Innovation Index in 0.5 points (at $10 \%$ confidence interval); 

Economy

- low inflation boosts innovative country development: an increase of Consumer Price Index in 1\% results in the increase of the dependent variable in 0.045 points (at $5 \%$ confidence interval);

- there is no statistically significant impact on the Global Innovation Index in 9 chosen countries of such factors as employment increase, expansion of net foreign direct investments and GDP growth;

- an increase of gross capital formation leads to an increase of the Global Innovation Index (at 1\% confidence interval);

- an increase of the trade openness in $1 \%$ results in the increase of the dependent variable in 0.3 points (at $1 \%$ confidence interval).

Table 3. Results of the regression analysis on testing the hypothesis about the influence of shadow economy on country innovative development in 9 countries in 2008-2018 (fixed effects model specification)

\begin{tabular}{|c|c|c|c|c|c|c|c|}
\hline \multirow{2}{*}{ Shadow } & \multirow{2}{*}{$\begin{array}{c}\text { Coefficients } \\
-0.500\end{array}$} & \multirow{2}{*}{$\begin{array}{c}\begin{array}{c}\text { Standard } \\
\text { Error }\end{array} \\
0.244\end{array}$} & \multirow{2}{*}{$\begin{array}{c}\begin{array}{c}\mathrm{t}- \\
\text { value }\end{array} \\
-1.95\end{array}$} & \multirow{2}{*}{$\begin{array}{c}\begin{array}{c}\mathrm{p}- \\
\text { value }\end{array} \\
0.105\end{array}$} & \multicolumn{2}{|c|}{$\begin{array}{l}95 \% \text { Confidence } \\
\text { Interval }\end{array}$} & \multirow{2}{*}{$\frac{\text { Sig }}{*}$} \\
\hline & & & & & -1.185 & 0.184 & \\
\hline CPI & 0.045 & 0.021 & 2.14 & 0.035 & 0.003 & 0.086 & $* *$ \\
\hline Empl & 0.010 & 0.253 & 0.04 & 0.969 & -0.494 & 0.514 & \\
\hline FDI & 0.000 & 0.000 & -0.43 & 0.668 & 0.000 & 0.000 & \\
\hline GDPg & -0.134 & 0.132 & -1.01 & 0.314 & -0.397 & 0.129 & \\
\hline GCF & 0.000 & 0.000 & 3.04 & 0.003 & 0.000 & 0.000 & *** \\
\hline Trade & 0.316 & 0.045 & 7.01 & 0.000 & 0.226 & 0.405 & $* * *$ \\
\hline Constant & 10.171 & 19.385 & 0.53 & 0.601 & -28.386 & 48.728 & \\
\hline \multicolumn{2}{|c|}{$\begin{array}{l}\text { Mean dependent } \\
\text { variable }\end{array}$} & 40.902 & \multicolumn{3}{|c|}{ SD dependent variable } & 7.074 & \\
\hline \multicolumn{2}{|c|}{ R-squared } & 0.653 & \multicolumn{3}{|c|}{ Number of observations } & 99.000 & \\
\hline \multicolumn{2}{|l|}{ F-test } & 22.291 & \multicolumn{3}{|c|}{ Probability $>\mathrm{F}$} & 0.000 & \\
\hline \multicolumn{2}{|c|}{ Akaike criterion (AIC) } & 538.844 & \multicolumn{3}{|c|}{ Bayesian criterion } & 554.415 & \\
\hline
\end{tabular}

Notes: ${ }^{* *}$ - significance at $1 \%$ level, ${ }^{* *}$ - significance at $5 \%$ level, ${ }^{*}$ - significance at $10 \%$ level, S.D. - standard deviation; GII - Global Innovation Index; Shadow - the ratio of the shadow economy in GDP; CPI - consumer price index; Empl - employment to population ratio; FDI - foreign direct investment, net; GCF - gross capital formation; GDPg - GDP growth; Trade - trade openness (ratio of total export and import amount to GDP).

Sources: developed by the authors.

Thus, we can conclude that for the whole country sample, it was confirmed the primary hypothesis. At the next stage of the research, the same hypothesis for Ukraine was tested by regression analysis. Results are presented in Table 4.

Table 4. Results of the regression analysis on testing the hypothesis about the influence of shadow economy on country innovative development in Ukraine in 2008-2018

\begin{tabular}{lcccccc}
\hline & Coefficients & $\begin{array}{c}\text { Standard } \\
\text { Error }\end{array}$ & $\begin{array}{c}\mathrm{t}- \\
\text { value }\end{array}$ & $\begin{array}{c}\mathbf{p}- \\
\text { value }\end{array}$ & \multicolumn{2}{c}{$\begin{array}{c}95 \% \text { Confidence } \\
\text { Interval }\end{array}$} \\
\hline Shadow & 5.441 & 4.437 & 1.23 & 0.308 & -8.680 & 19.563 \\
CPI & -0.062 & 0.084 & -0.74 & 0.514 & -0.328 & 0.204 \\
Empl & -0.032 & 4.394 & -0.01 & 0.995 & -14.016 & 13.953 \\
FDI & 0.000 & 0.000 & 1.57 & 0.214 & 0.000 & 0.000 \\
GDPg & 0.132 & 0.299 & 0.44 & 0.688 & -0.819 & 1.083 \\
GCF & 0.000 & 0.000 & 1.21 & 0.314 & 0.000 & 0.000 \\
\hline
\end{tabular}


A., Vysochyna, O., Kryklii, M., Minchenko, A. A., Alieva, K., Demchuk. Country Innovative Development: Impact of Shadow Economy

\begin{tabular}{lcclccc} 
& & & & \multicolumn{2}{c}{ Countinued Table 4 } \\
\hline Trade & 1.326 & 0.794 & 1.67 & 0.193 & -1.201 & 3.854 \\
Constant & -329.377 & 281.800 & -1.17 & 0.327 & -1226.191 & 567.436 \\
Mean dependent & & 33.833 & SD dependent variable & 4.916 \\
variable & & & \\
R-squared & 0.849 & Number of observations & 11.000 \\
F-test & 2.404 & Probability > F & 0.253 \\
Akaike criterion (AIC) & 58.432 & Bayesian criterion (BIC) & 61.218 \\
\hline
\end{tabular}

Notes: S.D. - standard deviation; GII - Global Innovation Index; Shadow - the ratio of the shadow economy in GDP; CPI - consumer price index; Empl - employment to population ratio; FDI - foreign direct investment, net; GCF - gross capital formation; GDPg - GDP growth; Trade --the Index of trade openness (ratio of total export and import amount to GDP).

Sources: developed by the authors.

Thus, in general terms it pointed out that the model is adequate, namely, the variation of the Global Innovation Index in Ukraine in $84.9 \%$ is explained by the variation of the independent and control variables. Nevertheless, there are no statistically significant relationships between the shadow economy and innovative country development in Ukraine. Consequently, we can mention that the hypothesis is not explicitly confirmed for Ukraine.

Conclusions. Nowadays, sustainable economic development at supranational, national and regional/municipal levels is impossible without large-scale and scientifically based financing of innovative development. Investments in innovations might be systemic and well-organised because of its efficiency and returns on investments depend on numerous external and internal determinants. The generalisation of theoretical research allows concluding that country innovative development and performance depends on many financial, social, material, institutional and labour determinants. While there are a lot of scientific papers that highlight the consequences of the expansion of innovations on the microeconomic level, there is a lack of them in terms of clarification its macroeconomic perspectives.

Therefore, it was realised a scientific approach aimed at to test the hypothesis about the negative influence of an expansion of shadow operations on dynamics of innovative country development based on data for 9 countries (Azerbaijan, Estonia, Hungary, Latvia, Lithuania, Poland, Slovak Republic, Slovenia, and Ukraine) in 2008-2018. Running of panel data regression analysis (model specification with fixed effects) allow confirming this hypothesis for the whole country sample (an increase of shadow economy negatively affected innovative country development: an increase of shadow economy to GDP ratio in $1 \%$ leads to the decrease of the Global Innovation Index in 0.5 points). However, it was not proved for Ukraine separately. This leads us to the conclusion that innovative development in Ukraine does not highly dependent on the shadow economy scale because of more significant obstacles on the way on innovation adoption (institutional inefficiency, regulatory drawbacks etc.).

Authors' contribution: Conceptualization and supervision, methodology, investigation and formal analysis, data curation and editing, writing: A. V.; O. K.; M. M.; A. A., K. D.

Funding: This paper was supported by and the National Research Foundation of Ukraine and the Ministry of Education and Science of Ukraine, and performed the results of the projects «Quadrocentric recursive model of de-shadowing of Ukraine's economy to increase its macroeconomic stability» (number of the state registration 0120U104798) and «Structural-functional multiplex model of ecological tax system building in Ukraine in the context of national security» (registration number 0119U100759) respectively. 


\section{References}

Akhondzadeh, A. (2019). Analysis of the Factors Affecting the Implementation of Virtual R\&D in Iranian Tile and Ceramic Companies Using Structural Equation Modeling Approach. [Google Scholar] [CrossRef].

AUgbaka, M., Awujola, A., \& Shcherbyna, T. (2019). Economic Development, Foreign Aid and Poverty Reduction: Paradigm in Nigeria. SocioEconomic Challenges, 3(4), 5-12. [Google Scholar]

Bhowmik, D. (2018). Financial Crises and Nexus Between Economic Growth and Foreign Direct Investment. Financial Markets, Institutions and Risks, 2(1), 58-74. [Google Scholar] [CrossRef]

Biewendt, M., Blaschke, F., \& Böhnert, A. (2020). An Evaluation Of Corporate Sustainability In Context Of The Jevons. SocioEconomic Challenges, 4(3), 46-65. [Google Scholar] [CrossRef]

Bonamigo, A., \& Mendes, D. (2019). Value Co-creation and Leadership: An Analysis Based on the Business Ecosystem Concept. Business Ethics and Leadership, 3(4), 66-73. [Google Scholar] [CrossRef]

Boyarko, I. M., \& Samusevych, Y. V. (2011). Role of intangible assets in company's value creation. Actual Problems of Economics, (117), 86-94.

Delanoy, N., \& Kasztelnik, K. (2020). Business Open Big Data Analytics to Support Innovative Leadership and Management Decision in Canada. Business Ethics and Leadership, 4(2), 56-74. [Google Scholar] [CrossRef].

Global Innovation Index Reports. (2020). Retrieved from [Link]

Goncharenko, T. (2020). From Business Modelling to the Leadership and Innovation in Business: Bibliometric Analysis (Banking as a Case). Business Ethics and Leadership, 4(1), 113-125. [Google Scholar] [CrossRef]

Hrytsenko, L. L., Roienko, V. V., \& Boiarko, I. M. (2018). Institutional background of the role of state in investment processes activation. Financial and credit activity: problems of theory and practice, 1(24), 338-344. [Google Scholar] [CrossRef]

Jahan, M. (2019). Factors Affecting Customer Satisfaction of the Ride-sharing Industry in Bangladesh. Business Ethics and Leadership, 3(4), 74-80. [Google Scholar] [CrossRef].

Kaya, H. D. (2020). Business Friendliness, Firm Performance and Owner's Optimism. Financial Markets, Institutions and Risks, 4(3), 13-23. [Google Scholar] [CrossRef]

Lopez, B. S., \& Alcaide, A.V. (2020). Blockchain, Al and loT to Improve Governance, Financial Management and Control of Crisis: Case Study COVID-19. SocioEconomic Challenges, 4(2), 78-89 [Google Scholar] [CrossRef]

Lyeonov, S., Kuzmenko, O., Yarovenko, H., \& Dotsenko, T. (2019). The Innovative Approach to Increasing Cybersecurity of Transactions Through Counteraction to Money Laundering. Marketing and Management of Innovations, 3, 308-326. [Google Scholar] [CrossRef].

Medina, L., \& Schneider, F. (2018). Shadow Economies Around the World: What Did We Learn Over the Last 20 Years? Retrieved from [Link].

Sadigov, M., Kuzmenko, O., \& Yarovenko, H. (2020). Blockchain technology based system-dynamic simulation modeling of enterprise's cyber security system. Economic and Social Development: Book of Proceedings, 399-408. [Google Scholar] Singh, S. N. (2018). Regional Disparity and Sustainable Development in NorthEastern States of India: A Policy Perspective. SocioEconomic Challenges, 2(2), 41-48. [Google Scholar]

Tommaso, F. D., \& Gulinelli, A. (2019). Corporate Governance and Economic Performance: The Limit of Short Termism. Financial Markets, Institutions and Risks, 3(4), 49-61. [Google Scholar] [CrossRef]

Toyin, O. W., \& Oludayol A. E. (2020). Dynamic Effects of Foreign Portfolio Investment on Economic Growth in Nigeria Financial Markets, Institutions and Risks, 4(3), 5-12. [Google Scholar] [CrossRef]

Tsalikis, J., \& Seaton, B. (2020). Corporate Social Responsibility: A Cross-National Study of the Treatment of Consumers and Employees. Business Ethics and Leadership, 4(2), 6-15. [Google Scholar] [CrossRef].

Umadia, Sr. K., \& Kasztelnik, K. (2020). The Financial Innovative Business Strategies of Small to Medium Scale Enterprises in Developing Country and Influence for the Global Economy Performance. SocioEconomic Challenges, 4(3), 20-32. [Google Scholar] [CrossRef]

Vasylieva, T. A., \& Kasyanenko, V. O. (2013). Integral assessment of innovation potential of Ukraine's national economy: A scientific methodical approach and practical calculations. Actual Problems of Economics, 144(6), 50-59.

Vasylieva, T., Lyeonov, S., Lyulyov, O., \& Kyrychenko, K. (2018). Macroeconomic Stability and Its Impact on the Economic Growth of the Country. Montenegrin Journal of Economics, 14(1), 159-170. [Google Scholar] [CrossRef] World Bank DataBank. (2020). Retrieved from [Link].

Yarovenko, H., Kuzmenko, O., \& Stumpo, M. (2020a). DEA-Analysis Of The Effectiveness Of The Country's Information Security System. SocioEconomic Challenges, 4(3), 142-153. [Google Scholar] [CrossRef]

Yarovenko, H., Kuzmenko, O., \& Stumpo, M. (2020b). Strategy for Determining Country Ranking by Level of Cybersecurity. Financial Markets, Institutions and Risks, 4(3), 124-137. [Google Scholar] [CrossRef]

Zolkover, A., \& Terziev, V. (2020). The Shadow Economy: A Bibliometric Analysis. Business Ethics and Leadership, 4(3), 107118. [Google Scholar] [CrossRef] 
A., Vysochyna, O., Kryklii, M., Minchenko, A. A., Alieva, K., Demchuk. Country Innovative Development: Impact of Shadow Economy

Аліна Височина, к.е.н., Сумський державний університету, Україна

Олена Криклій, к.е.н., Сумський державний університету, Україна

Марія Мінченко, к.е.н., Сумський державний університету, Україна

Аюгун Акбар Алієва, Ph.D., Iнститут Систем Управління Національної Академії Наук Азербайджану, Азербайджан Катерина Демчук, Університет прикладних наук Гамбурга, Німеччина

Інноваційний розвиток національної економіки: вплив тінізації економіки

У иій статті узагальнено аргументи та контраргументи в рамках наукової дискусії щодо визначення впливу незаконної економічної діяльності та розширення тіньової економіки на інноваційний розвиток країни. Систематизація наукових праць з вищезазначених проблем доводить, що у згаданих наукових працях немає комплексності та єдності, що, в свою чергу, доводить необхідність подальщого теоретичного та емпіричного пошуку в цій сфрері. Таким чином, у роботі була висунута наукова гіпотеза про негативний вплив тіньової економіки на інноваційний розвиток країни. Для перевірки цієї гіпотези був розроблений науково-методологічний підхід, що складається з декількох етапів: 1) кореляційний аналіз з метою усунення проблеми мультиколінеарності між змінними управління; 2) аналіз описової статистики набору даних; 3) проведення тесту Хаусмана з метою уточнення специфікації моделі регресії (модель фіксованих або випадкових ефектів); 4) реалізація панельного регресійного аналізу даних для всієї вибірки країни та окремо для України, характеристика її результатів. Технічно всі етапи дослідження реалізуються за допомогою програмного забезпечення Stata 12/SE. Вибірка дослідження складається 39 країн (Азербайджан, Естонія, Угорщина, Латвія, Литва, Польща, Словацька Республіка, Словенія та Україна). Часовий горизонт - 2008-2018. Запуск панельного регресійного аналізу даних (специфікація моделі - з фіксованими ефектами) дозволяє підтвердити гіпотезу дослідження для всієї вибірки країни (збільшення тіньової економіки негативно вплинуло на інноваційний розвиток країни: збільшення відношення тіньової економіки до ВВП на 1\% призводить до зниження Глобального індексу інновацій на 0,5 бала), але для України це окремо не доведено. Це підводить нас до висновку, що інноваційний розвиток в Україні не залежить від масштабу тіньової економіки через те, що ми маємо більш значні перешкоди на шляху до впровадження інновацій (інституційна неефективність, недоліки регулювання тощо).

Ключові слова: аналіз панельних даних, державний менеджмент інновацій, інноваційне економічне зростання, тіньова економіка.

Manuscript received: 30.10 .2020

(C) The author(s) 2020. This article is published with open access at Sumy State University 